\title{
Isoselenocyanates derived from Boc/Z-amino acids: synthesis, isolation, characterization, and application to the efficient synthesis of unsymmetrical selenoureas and selenoureidopeptidomimetics
}

\author{
Gundala Chennakrishnareddy ${ }^{\mathrm{a}}$, Govindappa Nagendra ${ }^{\mathrm{a}}$, Hosahalli P. Hemantha ${ }^{\mathrm{a}}$, Ushati Das ${ }^{\mathrm{b}}$, \\ Tayur N. Guru Row ${ }^{\mathrm{b}}$, Vommina V. Sureshbabu ${ }^{\mathrm{a}, *}$ \\ ${ }^{a}$ Peptide Research Laboratory, Department of Studies in Chemistry, Central College Campus, Bangalore University, Dr. B.R. Ambedkar Veedhi, Bangalore 560 001, India \\ ${ }^{\mathrm{b}}$ Solid State and Structural Chemistry Unit, Indian Institute of Science, Bangalore 560 012, India
}

\section{A R T I C L E I N F O}

\section{Article history:}

Received 21 May 2010

Received in revised form 22 June 2010

Accepted 29 June 2010

Available online 3 July 2010

\section{Keywords:}

Isoselenocyanates

Peptidomimetics

Selenoureas

Selenoureidopeptidomimetics

\begin{abstract}
A B S T R A C T
Isoselenocyanates derived from Boc/Z-amino acids are prepared by the reaction of the corresponding isonitriles with selenium powder in presence of triethylamine at reflux. The utility of these new classes of isoselenocyanates in the preparation of selenoureidodipeptidomimetics possessing both amino as well as carboxy termini has been accomplished. The ${ }^{1} \mathrm{H}$ NMR analysis confirmed that the protocol involving the conversion of isonitriles to isoselenocyanates and their use as coupling agents in assembling selenoureido derivatives is free from racemization.
\end{abstract}

(c) 2010 Elsevier Ltd. All rights reserved.

\section{Introduction}

Peptides and proteins, although, ubiquitous in living cells have to be modified chemically to make them employable as drugs and to prepare artificial enzymes. ${ }^{1-3}$ Ureidopeptides, peptidyl ureas, oligourea/peptide hybrids comprising either $\alpha$ and/or $\beta$-amino acid residues have been prepared and studied. ${ }^{4}$ Another new class of mimetics, thioureidopeptides was recently reported by us. ${ }^{5}$

Interest in the use of organoselenium compounds (OrgSeCs) in biochemistry is growing steadily ${ }^{6}$ due to (i) increase in the availability of stable OrgSeCs and (ii) the beneficial effects associated with them as antioxidants, enzyme inhibitors, cytokine inducers, immunomodulators, antitumor, antihypertensive, antiviral, antibacterial, antifungal, and anti-infective agents. ${ }^{7}$ Hundreds of OrgSeCs are being used as reagents and intermediates in organic synthesis. Woollins' reagent is regularly employed for various selenation reactions. ${ }^{8}$ Various strategies and reagents for the efficient incorporation of selenium functionality into molecular architecture are being developed. ${ }^{9-17}$ Their utility in the construction of several classes of heterocycles such as

\footnotetext{
* Corresponding author. Tel.: +9180 22961339; e-mail addresses: sureshbabuvommina@rediffmail.com, hariccb@gmail.com (V.V. Sureshbabu).
}

selenazoles ${ }^{18}$ and selenohydantoins ${ }^{19}$ is well documented. Selenosugars including glycosyl isoselenocyanates have been widely used in carbohydrate chemistry for the preparation of disaccharides, C-glycosides, O-glycosides, and glycoconjugates. ${ }^{20}$

The synthesis of Se-containing compounds is of interest in peptide science owing to the discovery of a number of selenoproteins. $^{21 \mathrm{a}, 22}$ Selenocysteine (Sec) is being viewed as 21 st proteinogenic amino acid because its insertion is genetically controlled. $^{21,23-26}$ Glutathione peroxidase (GPx), ${ }^{27}$ possessing Sec in the active site, is an antioxidant enzyme, which protects various organisms from oxidative damage. ${ }^{28}$ Selenocysteine mediated chemo-selective ligation is useful in chemical synthesis and semisynthesis of large peptides and a range of proteins through native chemical ligation. ${ }^{29}$ Despite the growing importance of selenopeptides/proteins, the insertion of Se into a peptide sequence is mainly limited to the above-described studies. ${ }^{30}$

Isoselenocyanates ${ }^{31}$ are easy to prepare and store, less toxic and safe to handle. Along with other applications, their utility especially in the synthesis of various selenium containing heterocycles is well documented. $^{32}$ Their preparation involves reaction of an isonitrile with Se or direct conversion of formamides into isoselenocyanates via the isonitrile intermediate. ${ }^{31 a, 33}$ Other important reports for their synthesis include the reaction of phenylimidolyl chloride with sodium selenide; isocyanates with phosphorous $(\mathrm{V})$ selenide; treatment of $\mathrm{N}$-aryl-carbimidic dichlorides with sodium selenide; 
photochemical rearrangement of selenocyanates; cycloaddition of nitrile oxides with primary selenoamide and alkylation of selenocyanate ion. ${ }^{34}$ An apparently convenient protocol would be the treatment of an amine with carbon diselenide, which is in very limited use due to the non availability of $\mathrm{CSe}_{2} \cdot{ }^{35}$ There are few other procedures available, which are yet to gain the merit of general applicability. $^{36}$

In the literature, isocyanates ${ }^{37}$ and isothiocyanates ${ }^{38,39}$ (2a and 2b) derived from amino/peptide acid esters as well as $\mathrm{N}$-protected amino acids are known to be employed as key synthons in both de novo design and for accessing biologically potent molecules $4,40-42$ (Fig. 1). Their utility as building blocks for the construction of uriedo/thioureido peptidomimetics has been the focus of several research publications ${ }^{37,38}$ (Figs. 1 and 2).

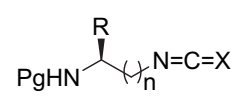

$$
1
$$

1a. Isocyanates: $X=0 ; n=0$ or 1 $\mathrm{Pg}=\mathrm{Fmoc}, \mathrm{Boc}$ or $\mathrm{Z}$ group. 1b. Isothiocyanates: $X=S ; n=1$ $\mathrm{Pg}=\mathrm{Fmoc}, \mathrm{Boc}$ or $\mathrm{Z}$ group.

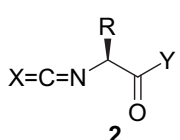

2a. Isocyanates: $X=0$ : $Y=$ OMe, OEt or OBzl group. 2b. Isothiocyanates: $X=S$; $\mathrm{Y}=\mathrm{OMe}, \mathrm{OEt}$ or OBzl group.

$$
\text { N-protected isoselenocyanates }
$$

Figure 1. Structures of isocyanates, isothiocyanates, and isoselenocyanates derived from amino acids.

\section{Results and discussion}

\subsection{Synthesis of isoselenocyanates 3 from $N$-Boc-amino acids}

The isonitriles precursors required for the preparation of respective class of isoselenocyanates were obtained by $\mathrm{LiAlH}_{4}$ reduction of the corresponding nitriles of the $\mathrm{N}$-Boc-amino acids followed by the formylation of the amine group as formamides $6{ }^{43}$ The dehydration of these formamides $\mathbf{6}$ afforded $N$ - $\beta$-Boc-amino alkyl isonitriles $\mathbf{7}$ in good yields. These novel classes of isonitriles could also be useful as precursors for well known multi-component reactions as well. ${ }^{43}$

As Sonoda et al. have reported that effective conversion of aliphatic isocyanides to corresponding isoselenocyanates requires an organic base such as TEA, ${ }^{31}$ we conceived the idea that the reaction of $N$ - $\beta$-Boc-amino alkyl isonitriles 7 with Se powder would offer new class of isoselenocyanates. In this context, a mixture of $1 \mathrm{mmol}$ each of $N^{\beta}$-Boc-Val- $\Psi\left[\mathrm{CH}_{2} \mathrm{NC}\right]$ 7a and Se powder in THF in presence of $0.7 \mathrm{mmol}$ of TEA was refluxed. The reaction was complete in $5-6 \mathrm{~h}$ as analyzed by TLC. The corresponding isoselenocyanate 3a was isolated in $90 \%$ yield. With this result, a series of isoselenocyanates $(\mathbf{3 a}-\mathbf{j})$ derived from corresponding Boc-amino acids were synthesized (Scheme 1), which could be stored for several weeks at subzero temperature without any decomposition. The IR spectrum of these isoselenocyanates exhibited a sharp peak at $2148 \mathrm{~cm}^{-1}$ characteristic of $-\mathrm{NCSe}$ group. While ${ }^{13} \mathrm{C}$ NMR spectrum showed characteristic signal at around $\delta 125$ corresponding to selenocarbonyl carbon while ${ }^{77}$ Se NMR spectrum possesses a signal at around $\delta-350$.

\section{2. $N$-Z-Amino alkyl isoselenocyanates 4}

Efficacy of the protocol for the synthesis of Boc-amino alkyl isoselenocyanates $\mathbf{3}$ prompted us to extend the study to the isonitrile derivatives of Z-amino acids $\mathbf{1 0}$, which were obtained through the dehydration of corresponding formamides $\mathbf{9}$, prepared by the formolysis of their isocyanates $\mathbf{8}$ by following our reported procedure. ${ }^{43,44}$ In the final step, the selenation of the isonitriles $\mathbf{1 0}$ was undertaken to afford $N^{\beta}-\mathrm{Z}-\mathrm{Xaa}-\Psi\left[\mathrm{CH}_{2} \mathrm{NCSe}\right] \mathrm{s} 4$ in satisfactory yield (Scheme 2).

Further, for the insertion of isoselenocyanate moiety in the side chain of an amino acid, the $\gamma$-carboxyl group of Glu was converted to the corresponding isonitrile using oxazolidinone as bidentate protection for $\alpha$-amino and carboxy groups. ${ }^{45} N^{\alpha}-\mathrm{Z}-\mathrm{Glu}-\mathrm{OH}$ derived oxazolidinone was prepared employing microwave assisted transformation of $\gamma$-carboxyl group of $N^{\alpha}-\mathrm{Z}-\mathrm{Glu}-\mathrm{OH}$ to formamide via formylation of corresponding isocyanate. It was dehydrated and converted to corresponding isoselenocyanate $\mathbf{1 1}$ as described before (Fig. 3).
In continuation of our interest in such mimetics, we now present our works on the syntheses of isoselenocyanates $\mathbf{3}$ and $\mathbf{1 1}$ derived from $\mathrm{N}$-Boc/Z-amino acids, hitherto unreported class of OrgSeCs and demonstrate their utility for the synthesis of selenoureido derivatives (Scheme 1).
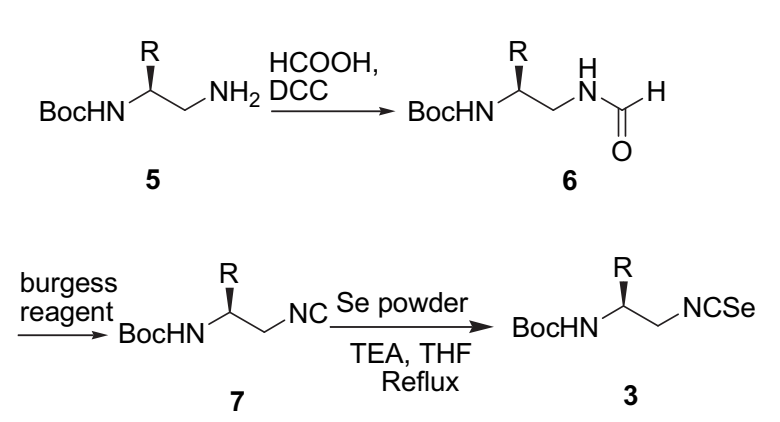

\begin{tabular}{lllcl} 
Sl. & Amino & \multicolumn{3}{c}{ Yield (\%) } \\
No. & acid & $\mathbf{6}$ & $\mathbf{7}$ & $\mathbf{3}$ \\
1 & Val & 89 & 89 & 90 \\
2 & Leu & 88 & 92 & 95 \\
3 & Ile & 89 & 90 & 92 \\
4 & Phe & 91 & 95 & 96 \\
5 & Phg & 92 & 93 & 89 \\
6 & Pro & 80 & 88 & 85 \\
7 & Met & 88 & 93 & 88 \\
8 & Cys(Bzl) & 87 & 91 & 80 \\
9 & Ser(Bzl) & 82 & 90 & 86 \\
10 & Aib & 82 & 90 & 92
\end{tabular}

Scheme 1. Preparation of isoselenocyanates 3 derived from Boc-amino acids and the respective yields. 


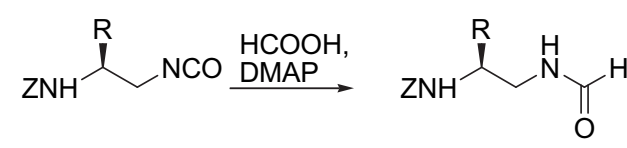

8

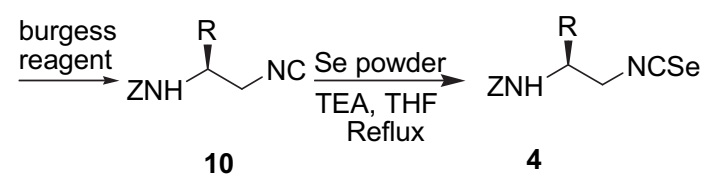

\begin{tabular}{lllcc} 
Sl. & Amino & \multicolumn{3}{c}{ Yield (\%) } \\
No. & acid & $\mathbf{9}$ & $\mathbf{1 0}$ & $\mathbf{4}$ \\
1 & Ala & 82 & 82 & 91 \\
2 & Val & 87 & 92 & 84 \\
3 & Leu & 85 & 85 & 83 \\
4 & Ile & 82 & 89 & 88 \\
5 & Phe & 90 & 93 & 90 \\
6 & Pro & 75 & 80 & 77 \\
7 & Met & 86 & 83 & 88 \\
8 & Cys(Bzl) & 79 & 79 & 75 \\
9 & Ser(Bzl) & 76 & 81 & 76 \\
10 & Lys(Boc) & 75 & 74 & 79 \\
& & & &
\end{tabular}

Scheme 2. Preparation of isoselenocyanates $\mathbf{4}$ derived from Z-amino acids.<smiles></smiles>

Figure 3. Structure of isoselenocyanate derived from Z-Glu-5-oxazolidinone.

\subsection{Synthesis of unsymmetrical selenoureas $12 a-e$ and selenoureidopeptides $13 a-f$}

In general, selenoureas are prepared by the reaction of an isoselenocyanate with an amino component. ${ }^{9 a, 46}$ In order to demonstrate the synthetic utility of the isoselenocyanates $\mathbf{3}$ and $\mathbf{4}$, five unsymmetrical selenoureas were prepared. In the first set of experiments 3a, 3b, 3d, 4d, 11e were made to react with five different aromatic amines (Scheme 3, Table 1). All the selenoureas 12a-e were obtained in good yield after column chromatographic purification using ethyl acetate/hexane (9:1). However, the reaction of 3 with aromatic amines possessing electron-withdrawing groups attached to the aromatic nucleus failed to form corresponding selenoureas. Among the various spectral data recorded for these selenoureas, the chemical shifts of compounds 12 and 13 in ${ }^{77} \mathrm{Se}$ NMR were observed approximately at $\delta 280$.

Our long-term interest in the area of peptidomimetics has resulted in the design and insertion of ureido/thioureido moiety
[ $-\mathrm{NH}-\mathrm{CX}-\mathrm{NH}-, \mathrm{X}=\mathrm{O}$ or $\mathrm{S}]$ in place of peptide bond. In this direction, we have now prepared six selenoureidodipeptides 13a-f. It has been found that the reaction of $\mathbf{3}$ or $\mathbf{4}$ with an amino acid ester was clean and complete within $30 \mathrm{~min}$ at room temperature (Scheme 3). After regular workup, the selenoureido products 13a-f were obtained in about $90 \%$ yield (Table 1 ).

\subsection{Tests for racemization}

Racemization while formation of the isoselenocyanates and during the coupling with amines as well as amino acid esters was expected to be unlikely considering the mild conditions chosen for the functional group transformations. However, as the penultimate part of this study, we undertook the synthesis of three sets of epimeric selenoureas. In the first two sets, Boc- - Phe $-\Psi\left[\mathrm{CH}_{2} \mathrm{NCSe}\right] 3 \mathbf{3}$, and $\mathrm{Z}-\mathrm{L}-\mathrm{Phe}-\Psi\left[\mathrm{CH}_{2} \mathrm{NCSe}\right]$ 4e were coupled with $(R)-,(S)$ - and a racemic mixture of 1-phenylethylamine in parallel experiments and six selenoureas $14 \mathbf{a}-\mathbf{c}$ and $15 \mathbf{a}-\mathbf{c}$ were isolated (Fig. 4). In each set, ${ }^{1} \mathrm{H}$ NMR of the particular epimers contained a single distinct methyl group doublet. Observed $\delta$ values for the $-\mathrm{CH}_{3}$ group of the compounds are as follows: 14a: $1.34,1.32$ and 14b: $1.26,1.24$; 15a: $1.50,1.48$ and 15b: $1.56,1.54$. Further, the compounds $14 c$ and $15 c$, prepared by coupling the corresponding isoselenocyanates with racemic 1 phenylethylamine showed two distinct doublets in each case

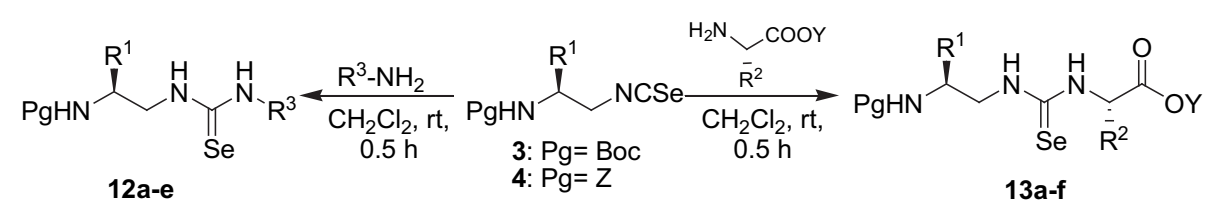

Scheme 3. Synthesis of selenoureas 12 and selenoureidopeptides 13.

Table 1

List of selenoureas $\mathbf{1 2}$ and selenoureidodipeptides $\mathbf{1 3}$ synthesized

\begin{tabular}{|c|c|c|c|c|c|c|c|c|c|c|}
\hline Entry & $\mathrm{Pg}$ & $\mathrm{R}^{1}$ & $\mathrm{R}^{3}$ & Yield (\%) & Entry & $\mathrm{Pg}$ & $\mathrm{R}^{1}$ & $\mathrm{R}^{2}$ & $\mathrm{Y}$ & Yield (\%) \\
\hline $12 c$ & Boc & $\mathrm{CH}_{2} \mathrm{CH}\left(\mathrm{CH}_{3}\right)_{2}$ & & 98 & $13 c$ & Boc & $\mathrm{CH}_{2} \mathrm{CH}\left(\mathrm{CH}_{3}\right)_{2}$ & $\mathrm{H}$ & Me & 98 \\
\hline \multirow[t]{2}{*}{$12 e$} & Z & $\mathrm{CH}\left(\mathrm{CH}_{3}\right)\left(\mathrm{C}_{2} \mathrm{H}_{5}\right)$ & & 98 & $13 e$ & Z & $\mathrm{CH}\left(\mathrm{CH}_{3}\right)_{2}$ & $\mathrm{CH}\left(\mathrm{CH}_{3}\right)\left(\mathrm{C}_{2} \mathrm{H}_{5}\right)$ & Bzl & 90 \\
\hline & & & & & $13 \mathrm{f}$ & Z & $\mathrm{CH}_{2} \mathrm{CH}\left(\mathrm{CH}_{3}\right)_{2}$ & $\mathrm{CH}\left(\mathrm{CH}_{3}\right)_{2}$ & $\mathrm{Me}$ & 92 \\
\hline
\end{tabular}



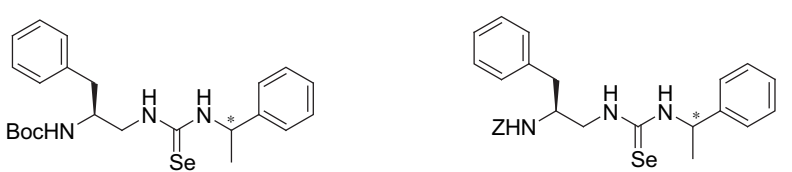

14a: $R$ at *; 14b $S$ at *; 14c: $R$ and $S$ at *

15a: $R$ at *; $15 \mathrm{~b}: S$ at *; $15 \mathrm{c}: R$ and $S$ at *

Figure 4. Epimeric diselenoureidopeptides synthesized for racemization studies.

suggesting the presence of two isomers, which confirms the absence of racemization.

\subsection{Crystal structures of Boc-Phe $-\Psi\left[\mathrm{CH}_{2} \mathrm{NC}\right] 7 \mathrm{~d}$, Boc-Val- $-\Psi$ $\left[\mathrm{CH}_{2} \mathrm{NCSe}\right]$ 3a, Boc-Phe $-\Psi\left[\mathrm{CH}_{2} \mathrm{NCSe}\right]$ 3d, and $\mathrm{Z}-\mathrm{Leu}-\Psi$ $\left[\mathrm{CH}_{2} \mathrm{NCSe}\right] 4 \mathrm{c}$}

It is important to mention that not many $N$-protected amino acid derived synthons have been crystallized although a small portion of conformationally restricted amino acid derivatives are studied through X-ray crystallography. Recently, we had reported the crystal structure of novel $\mathrm{N}$-Boc-amino alkyl isothiocyanates obtained from Gly and Phe. ${ }^{21}$ Guichard's group reported the crystal structures of succinimidyl carbamates of Boc-Pro-OH and Boc-Pro-Val-OH, which were derived from their corresponding isocyanates. ${ }^{41 \mathrm{c}}$ In the present work, three isoselenocyanates namely, Boc-Val- $\Psi$ $\left[\mathrm{CH}_{2} \mathrm{NCSe}\right]$ 3a, Boc-Phe- $\Psi\left[\mathrm{CH}_{2} \mathrm{NCSe}\right]$ 3d, $\mathrm{Z}-\mathrm{Leu}-\Psi\left[\mathrm{CH}_{2} \mathrm{NCSe}\right] \mathbf{4 c}$, and an isonitrile Boc-Phe- $\Psi\left[\mathrm{CH}_{2} \mathrm{NC}\right]$ 7d have been isolated as crystals and their structures have been determined. To the best of our knowledge, this is the first report on the crystal structure analysis of amino acid derivatives containing an isocyano group or isoselenocyanato group.

Boc-Phe $-\Psi\left[\mathrm{CH}_{2} \mathrm{NC}\right]$ 7d crystallizes in the orthorhombic crystal system in the non-centrosymmetric space group $P 22_{1} 2_{1}$ with $Z^{\prime}=1$. Compound 7d (Fig. 5) shows the asymmetric unit and the atom-numbering scheme (see Supplementary data). In the asymmetric unit, the plane of the phenyl ring is tilted from the rest of the molecule at a dihedral angle C5-C6-C11-C15 of $74.91^{\circ}$. As expected, the $\mathrm{C}-\mathrm{N}^{+} \equiv \mathrm{C}$ bond is nearly linear, with a $\mathrm{C} 10-\mathrm{N} 2-\mathrm{C} 14$ angle of $178.33^{\circ}$. The molecular assembly is chiefly stabilized by an extensive network of $\mathrm{N}-\mathrm{H} \cdots \mathrm{O}$ strong

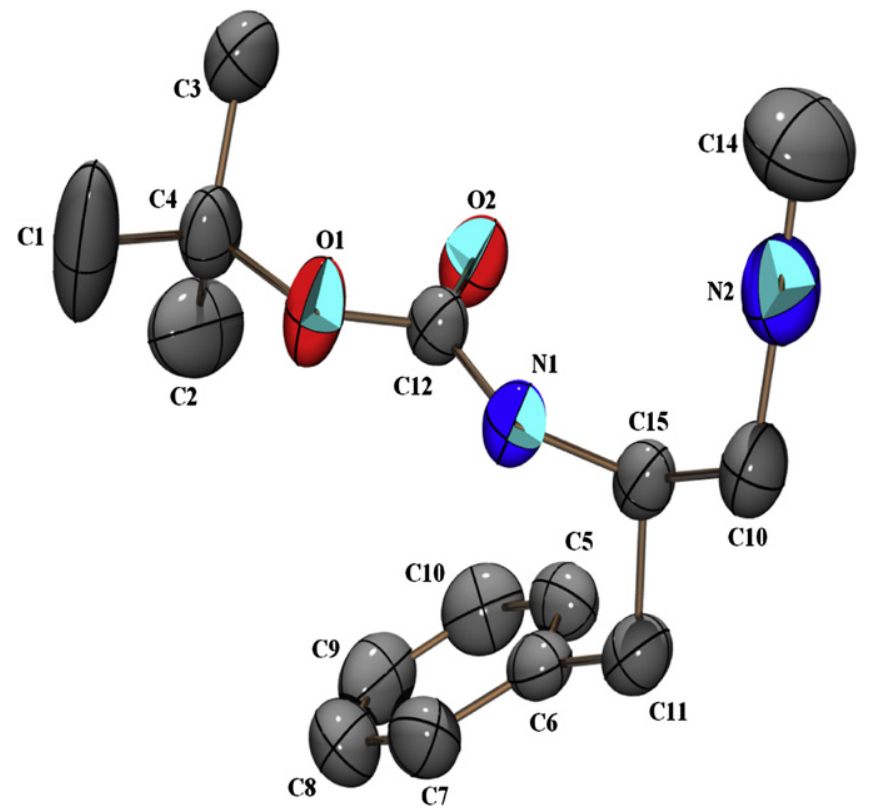

Figure 5. Crystal structure of Boc-Phe- $\Psi\left[\mathrm{CH}_{2} \mathrm{NC}\right]$ 7d showing the atom-numbering scheme. Displacement ellipsoids are drawn at the $50 \%$ probability level and $\mathrm{H}$ atoms have been omitted for the sake of clarity. hydrogen bonds in the ac plane, wherein the nitrogen atom of the amino group acts as a donor to the hydrogen bond acceptor, oxygen of the carbonyl moiety. The $\mathrm{N}-\mathrm{H} \cdots \mathrm{O}$ interactions are further supplemented with $\mathrm{C}-\mathrm{H} \cdots \pi$ weak interactions along the $a$ axis.

Boc-Val- $\Psi\left[\mathrm{CH}_{2} \mathrm{NCSe}\right]$ 3a and Boc-Phe- $\Psi\left[\mathrm{CH}_{2} \mathrm{NCSe}\right]$ 3d crystallize in the orthorhombic crystal system in the non-centrosymmetric space group $P 2_{1} 2_{1} 2_{1}$ with $Z^{\prime}=1$ and in the asymmetric unit, the $\mathrm{N}=\mathrm{C}=$ Se bond is nearly linear with an angle of $177.79^{\circ}$ and $178.59^{\circ}$, respectively. The $\mathrm{Z}-\mathrm{Leu}-\Psi\left[\mathrm{CH}_{2} \mathrm{NCSe}\right] \mathbf{4 c}$ crystallize in the monoclinic crystal system in the non-centrosymmetric space group $P 21$, with $Z^{\prime}=1$ with $\mathrm{N}=\mathrm{C}=$ Se bond almost linear at an angle of $178.68^{\circ}$ (Fig. 6 ). The selected bond lengths, crystal data and structure refinement parameters, selected torsion angles, and hydrogen bonding geometry of the above crystals have been furnished in Supplementary data.

\section{Summary}

In summary, we have delineated a simple protocol for the preparation of new classes of isoselenocyanates derived from Boc as well as Z-protected amino acids. These two classes of chiral OrgSeCs were isolated in good yields and fully characterized. The isoselenocyanates $\mathbf{3}$ and $\mathbf{4}$ are storable at $0^{\circ} \mathrm{C}$. Three samples of $\mathrm{N}$-Boc/Z-amino acid derived isoselenocyanates were obtained as single crystals and their structure was confirmed through X-ray crystallography. Straightforward reaction of isoselenocyanates $\mathbf{3}$ and 4 with amino components has yielded selenoureidopeptidomimetics and unsymmetrical selenoureas.

\section{Experimental}

\subsection{General}

All amino acids were used as obtained from Sigma-Aldrich Company, USA. Unless or otherwise mentioned, all amino acids used were of L-configuration. All the solvents were dried and purified using recommended procedures in the literature whenever necessary. High resolution mass spectra were recorded on a Micromass Q-TOF micromass spectrometer using electron spray ionization mode, elemental analyses were carried out using Carlo Erba $1106 \mathrm{CHN}$ analyzer, ${ }^{1} \mathrm{H}$ NMR and ${ }^{13} \mathrm{C}$ NMR spectra were recorded on a Bruker AMX $300 \mathrm{MHz}$ and $100 \mathrm{MHz}$ spectrometer, respectively, at the Indian Institute of Science, Bangalore. IR spectra were recorded on a Schimadzu model FT-IR spectrometer at Bangalore University, Bangalore. Melting points were determined in an open capillary and are uncorrected. TLC experiments were done using MERCK TLC aluminum sheets (silica gel $60 \quad F_{254}$ ) and chromatograms were visualized by exposing in iodine chamber, UV-lamp or spraying with $\mathrm{KMnO}_{4}$, and heating. Column chromatography was performed on silica gel (100-200 mesh) using ethyl acetate and hexane mixtures as eluent.

\subsection{Typical procedure for formamides derived from Boc- amino acids 6}

To the $\mathrm{CH}_{2} \mathrm{Cl}_{2}$ solution of $N$-Boc- $\beta$-amino alkyl amine $(10.0 \mathrm{mmol}$ 5) at $0{ }^{\circ} \mathrm{C}$ were added ethyl-3-(3-dimethylaminopropyl)carbodiimide (EDC) $(2.1 \mathrm{~g}, 11.0 \mathrm{mmol})$ and $98 \%$ of formic acid $(0.42 \mathrm{~mL}$, $11.0 \mathrm{mmol}$ ). After stirring the mixture for $3 \mathrm{~h}$, the reaction mixture was filtered and the filtrate was evaporated under reduced pressure. The crude mixture was diluted with $\mathrm{CH}_{2} \mathrm{Cl}_{2}(20 \mathrm{~mL})$ and was washed with $5 \% \mathrm{Na}_{2} \mathrm{CO}_{3}$, water, and brine, dried over anhydrous sodium sulfate, and the solvent was removed in vacuo. The crude was subjected to column purification (Silicagel 100-200 mesh, 20\% EtOAc/ hexane). 


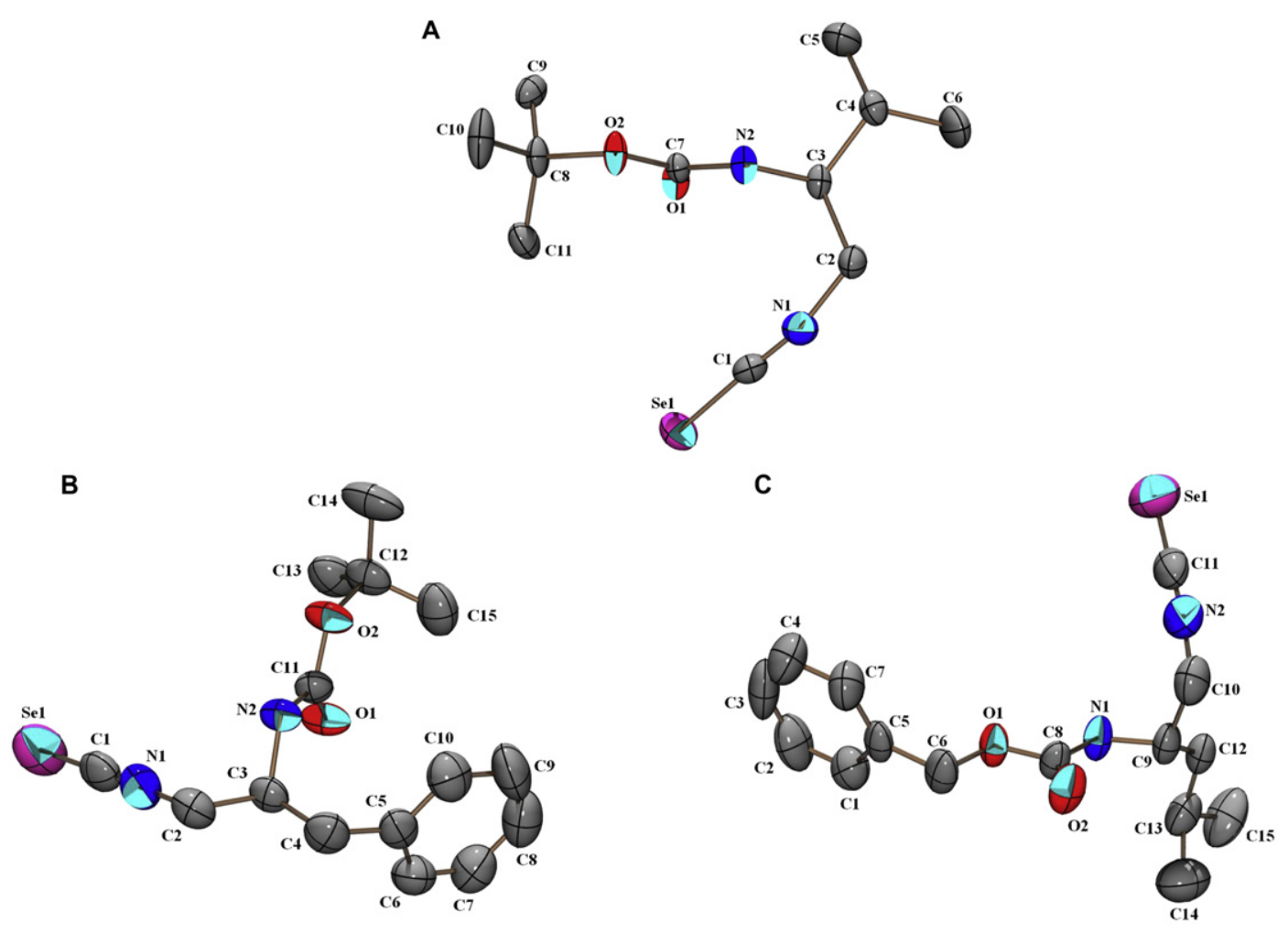

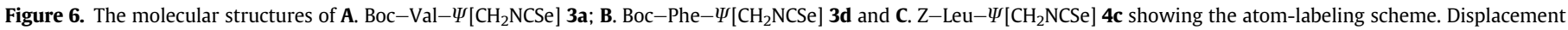
ellipsoids are drawn at the $50 \%$ probability level and $\mathrm{H}$ atoms have been omitted for the sake of clarity.

4.2.1. (S)-tert-Butyl 1-formamido-3-methylbutan-2-ylcarbamate (Boc-Val- $\Psi\left[\mathrm{CH}_{2} \mathrm{NHCHO}\right]$ ) (6a). Compound 6 a was prepared by the above method and purified by column chromatography using 5:1 hexanes/EtOAc to afford $\mathbf{6 a}(89 \%)$ as a white solid: $\mathrm{mp} 74-76{ }^{\circ} \mathrm{C} ; R_{f}$ value 0.24 (n-hexane/EtOAc 1:1); $[\alpha]_{\mathrm{D}}^{25}-4.1\left(\right.$ c $\left.1.0, \mathrm{CHCl}_{3}\right)$; IR $(\mathrm{KBr}) \nu$ 1654,$1710 ;{ }^{1} \mathrm{H}$ NMR $\left(300 \mathrm{MHz}\right.$, DMSO- $\left.d_{6}\right) \delta 0.95(6 \mathrm{H}, \mathrm{d}, J=6.7 \mathrm{~Hz},-\mathrm{CH}$ $\left.\left(\mathrm{CH}_{3}\right)_{2}\right), 1.42\left(9 \mathrm{H}, \mathrm{s},-\mathrm{C}\left(\mathrm{CH}_{3}\right)_{3}\right), 1.65-1.88\left(1 \mathrm{H}, \mathrm{m},-\mathrm{CH}\left(\mathrm{CH}_{3}\right)_{2}\right)$, $3.25-3.37\left(2 \mathrm{H}, \mathrm{m},-\mathrm{CH}_{2}-\mathrm{NHCHO}\right), 4.08\left(1 \mathrm{H}, \mathrm{m},-\mathrm{CH}-\mathrm{CH}_{2}-\right), 6.62(1 \mathrm{H}$, $\mathrm{m}, \mathrm{NH}), 8.05(1 \mathrm{H}, \mathrm{m},-\mathrm{NHCHO}) ;{ }^{13} \mathrm{C}$ NMR (100 MHz, DMSO-d $\left.d_{6}\right) \delta 18.5$, 19.3, 28.3, 29.1, 44.1, 54.2, 79.7, 155.4, 162.3; MS (ESI-HR) $\mathrm{m} / \mathrm{z}$ calcd for $\mathrm{C}_{11} \mathrm{H}_{22} \mathrm{~N}_{2} \mathrm{NaO}_{3} 253.1528\left(\mathrm{M}+\mathrm{Na}^{+}\right)$, found $253.1525\left(\mathrm{M}+\mathrm{Na}^{+}\right)$.

\subsection{Typical procedure for formamides derived from $\mathrm{Z}$-amino acids 9}

To a THF solution of $\mathrm{N}$-Z- $\beta$-amino acid $(10.0 \mathrm{mmol})$ at $-20^{\circ} \mathrm{C}$ were added $N$-methylmorpholine $(1.21 \mathrm{~mL}, 11.0 \mathrm{mmol}$ ) and ethyl chloroformate ( $1.05 \mathrm{~mL}, 11.0 \mathrm{mmol}$ ). After stirring the mixture for $10 \mathrm{~min}$, aq sodium azide ( $975 \mathrm{mg}, 15 \mathrm{mmol}$ ) was added and the stirring was continued until completion of the reaction (TLC analysis). The reaction mixture was concentrated under vacuum and the residue was dissolved in $30.0 \mathrm{~mL}$ of $\mathrm{CH}_{2} \mathrm{Cl}_{2}$. The organic layer was washed with $20 \mathrm{~mL}$ each of $5 \% \mathrm{Na}_{2} \mathrm{CO}_{3}, 10 \%$ citric acid, water, and brine, dried over anhydrous sodium sulfate, and evaporated under reduced pressure. The resulting residue was dissolved in $15.0 \mathrm{~mL}$ of toluene and heated at $65{ }^{\circ} \mathrm{C}$ for $30 \mathrm{~min}$ under argon. Upon complete formation of the isocyanate (strong IR peak at $2220 \mathrm{~cm}^{-1}$ and absence of azide peak at $2100 \mathrm{~cm}^{-1}$ ), toluene was removed in vacuo. The isocyanates obtained were dissolved in $15 \mathrm{~mL}$ of dry $\mathrm{CH}_{2} \mathrm{Cl}_{2}$ and the solution was stirred at $-15{ }^{\circ} \mathrm{C}$ with the addition of $98 \%$ formic acid $(0.77 \mathrm{~mL}, 20 \mathrm{mmol})$ and DMAP (36 mg, $0.3 \mathrm{mmol}$ ), till the end of the reaction. The reaction mixture was diluted with $\mathrm{CH}_{2} \mathrm{Cl}_{2}$ and washed with $20 \mathrm{~mL}$ each of $10 \%$ citric acid, $5 \% \mathrm{Na}_{2} \mathrm{CO}_{3}$, water, and brine solution and dried over anhydrous $\mathrm{Na}_{2} \mathrm{SO}_{4}$ and the solvent was evaporated under vaccum. The crude was subjected to column purification (Silicagel 100-200 mesh, 20\% EtOAc/n-hexane).

4.3.1. (S)-Benzyl 1-formamido-4-(methylthio)butan-2-ylcarbamate (Z-Met- $\left.-\Psi\left[\mathrm{CH}_{2} \mathrm{NHCHO}\right]\right)(\mathbf{9 g})$. Compound 9a was prepared by the above method and purified by column chromatography using 5:1 hexanes/EtOAc to afford 9a (86\%) as a white solid: $\mathrm{mp}$ $124-126^{\circ} \mathrm{C} ; R_{f}$ value 0.22 ( $n$-hexane/EtOAc $1: 1$ ); $[\alpha]_{\mathrm{D}}^{25}-20.3$ (c 1.0, $\left.\mathrm{CHCl}_{3}\right)$; IR (KBr) $\nu 1666,1703 ;{ }^{1} \mathrm{H}$ NMR $\left(300 \mathrm{MHz}, \mathrm{CDCl}_{3}\right) \delta 1.61-1.72$ $\left(2 \mathrm{H}, \mathrm{m}, \mathrm{CH}_{3}-\mathrm{S}-\mathrm{CH}_{2} \mathrm{CH}_{2}-\right), 2.04\left(3 \mathrm{H}, \mathrm{s}, \mathrm{CH}_{3}-\mathrm{S}-\right), 2.47-2.58(2 \mathrm{H}, \mathrm{m}$, $\left.\mathrm{CH}_{3}-\mathrm{S}-\mathrm{CH}_{2}-\right)$, 3.27-3.45 (2H, m, $\left.-\mathrm{CH}_{2}-\mathrm{NHCHO}\right), 3.82(1 \mathrm{H}, \mathrm{m}$, $\left.-\mathrm{CH}-\mathrm{CH}_{2}-\right), 5.02\left(2 \mathrm{H}, \mathrm{s}, \mathrm{Ar}-\mathrm{CH}_{2}\right), 6.30(1 \mathrm{H}, \mathrm{br}, \mathrm{NH}), 7.12-7.32(5 \mathrm{H}$, $\mathrm{m}, \mathrm{ArH}), 8.20(1 \mathrm{H}, \mathrm{s},-\mathrm{NHCHO}) ;{ }^{13} \mathrm{C} \mathrm{NMR}\left(100 \mathrm{MHz}, \mathrm{CDCl}_{3}\right) \delta 16.0$, 29.6, 31.8, 43.4, 54.1, 66.2, 127.3, 128.0, 128.7, 136.1, 156.4, 162.6; MS (ESI-HR) $\mathrm{m} / z$ calcd for $\mathrm{C}_{14} \mathrm{H}_{20} \mathrm{~N}_{2} \mathrm{NaO}_{3} \mathrm{~S} 319.1092\left(\mathrm{M}+\mathrm{Na}^{+}\right)$, found $319.1096\left(\mathrm{M}+\mathrm{Na}^{+}\right)$.

\subsection{General procedure for the preparation $\mathrm{N}$-Boc/Z-amino acid derived isonitriles 7 and $\mathbf{1 0}$}

Burgess reagent $(3.57 \mathrm{~g}, 15.0 \mathrm{mmol})$ was added to a solution of formamide $\mathbf{6} \mathbf{a}-\mathbf{j}$ or $\mathbf{9 a}-\mathbf{j}(10.0 \mathrm{mmol})$ in dry $\mathrm{CH}_{2} \mathrm{Cl}_{2}(20 \mathrm{~mL})$ and the resulting solution was refluxed till completion of the reaction (TLC). It was diluted with $\mathrm{CH}_{2} \mathrm{Cl}_{2}(10 \mathrm{~mL})$ and washed with water $(2 \times 10 \mathrm{~mL})$, brine $(10 \mathrm{~mL})$, dried over anhydrous sodium sulfate and was concentrated in vacuo to obtain the crude product that was purified by column chromatography (100-200 mesh silica gel) using $10 \%$ ethyl acetate in hexane. Alternatively, the reaction mixture was concentrated in vacuo and the crude compound was purified by column chromatography to obtain pure isonitrile.

4.4.1. (S)-tert-Butyl 1-isocyano-4-methylpentan-2-ylcarbamate (Boc-Leu- $\Psi\left[\mathrm{CH}_{2} \mathrm{NC}\right]$ ) (7b). Compound $\mathbf{7 b}$ was prepared by the above method and purified by column chromatography using 9:1 
hexanes/EtOAc to afford $\mathbf{7 b}(92 \%)$ as a white solid: $\mathrm{mp} 55-57{ }^{\circ} \mathrm{C} ; R_{f}$ value 0.47 (n-hexane/EtOAc 4:1); $[\alpha]_{\mathrm{D}}^{25}-22.4$ (c 1.0, $\mathrm{CHCl}_{3}$ ); $\mathrm{IR}(\mathrm{KBr}) \nu$ 1687, 2146; ${ }^{1} \mathrm{H}$ NMR $\left(300 \mathrm{MHz}, \mathrm{CDCl}_{3}\right) \delta 1.01(6 \mathrm{H}, \mathrm{d}, J=5.6 \mathrm{~Hz},-\mathrm{CH}$ $\left.\left(\mathrm{CH}_{3}\right)_{2}\right), 1.48\left(9 \mathrm{H}, \mathrm{s},-\mathrm{C}\left(\mathrm{CH}_{3}\right)_{3}\right), 1.72-1.80\left(2 \mathrm{H}, \mathrm{m},-\mathrm{CH}_{2}-\mathrm{CH}\left(\mathrm{CH}_{3}\right)_{2}\right)$, $1.88\left(1 \mathrm{H}, \mathrm{m},-\mathrm{CH}\left(\mathrm{CH}_{3}\right)_{2}\right), 3.43-3.64\left(2 \mathrm{H}, \mathrm{m},-\mathrm{CH}-\mathrm{CH}_{2}-\right), 4.11(1 \mathrm{H}, \mathrm{m}$, $\left.-\mathrm{CH}-\mathrm{CH}_{2}-\right), 5.28(1 \mathrm{H}, \mathrm{br}, \mathrm{NH}) ;{ }^{13} \mathrm{C} \mathrm{NMR}\left(100 \mathrm{MHz}, \mathrm{CDCl}_{3}\right) \delta 22.0,23.9$, 24.1, 28.2, 40.7, 47.4, 49.4, 80.1, 154.3, 156.2; MS (ESI-HR) $\mathrm{m} / z$ calcd for $\mathrm{C}_{12} \mathrm{H}_{22} \mathrm{~N}_{2} \mathrm{NaO}_{2} \mathrm{~m} / z 249.1579\left(\mathrm{M}+\mathrm{Na}^{+}\right)$, found $249.1575\left(\mathrm{M}+\mathrm{Na}^{+}\right)$.

4.4.2. (S)-Benzyl 1-isocyano-3-phenylpropan-2-ylcarbamate (Z-Phe-U $\left.\left[\mathrm{CH}_{2} \mathrm{NC}\right]\right)(\mathbf{1 0 e})$. Compound 10e was obtained as a white solid (93\%): mp 130-132 ${ }^{\circ} \mathrm{C} ; R_{f}$ value 0.45 ( $n$-hexane/EtOAc 4:1); $[\alpha]_{\mathrm{D}}^{25}-16.0(\mathrm{c}$ 1.0, $\left.\mathrm{CHCl}_{3}\right)$; IR (KBr) $\nu 1697,2148 ;{ }^{1} \mathrm{H}$ NMR (300 MHz, $\left.\mathrm{CDCl}_{3}\right)$ $\delta 2.34-2.48\left(2 \mathrm{H}, \mathrm{m},-\mathrm{CH}-\mathrm{CH}_{2}-\mathrm{Ar}\right), 3.36-3.51\left(2 \mathrm{H}, \mathrm{m},-\mathrm{CH}_{2}-\mathrm{NC}\right)$, $3.92\left(1 \mathrm{H}, \mathrm{m},-\mathrm{CH}-\mathrm{CH}_{2}-\mathrm{NC}\right), 5.12\left(2 \mathrm{H}, \mathrm{s}, \mathrm{Ar}-\mathrm{CH}_{2}\right), 5.68(1 \mathrm{H}, \mathrm{br}, \mathrm{NH})$, 7.13-7.46 (10H, m, $\mathrm{ArH}) ;{ }^{13} \mathrm{C}$ NMR (100 MHz, $\left.\mathrm{CDCl}_{3}\right) \delta 39.8,42.4$, 52.9, 67.3, 127.5, 128.4, 128.4, 128.9, 129.2, 130.1, 136.8, 137.9, 157.7, 163.0; MS (ESI-HR) $m / z$ calcd for $\mathrm{C}_{18} \mathrm{H}_{18} \mathrm{~N}_{2} \mathrm{NaO}_{2} 317.1266\left(\mathrm{M}+\mathrm{Na}^{+}\right)$, found $317.1256\left(\mathrm{M}+\mathrm{Na}^{+}\right)$.

\subsection{General procedure for the synthesis of isoselenocyanates 3 and 4}

To a solution of $\mathrm{N}$-Boc/Z-amino acid derived isonitriles $\mathbf{7}$ or $\mathbf{1 0}$ $(1 \mathrm{mmol})$ in dry THF $(12 \mathrm{~mL})$, TEA $(0.97 \mathrm{~mL}, 0.7 \mathrm{mmol})$ and selenium powder $(2.37 \mathrm{~g}, 3 \mathrm{mmol})$ were added. It was refluxed for a minimum of $5 \mathrm{~h}$. After the completion of reaction (TLC), it was allowed to cool to room temperature and was passed through a pad of Celite. The filtrate was diluted with ethyl acetate $(15 \mathrm{~mL})$ and washed with dilute citric acid $(10 \mathrm{~mL} \times 2)$, water $(10 \mathrm{~mL} \times 2)$, and brine $(10 \mathrm{~mL})$. The organic phase was dried over anhydrous sodium sulfate and concentrated. The crude was purified by column chromatography (silica gel 100-200 mesh, 10\% ethyl acetate in hexane) to afford the product as crystalline solid.

4.5.1. (S)-tert-Butyl 1-isoselenocyanato-4-methylpentan-2-ylcarbamate (Boc-Leu- $\Psi\left[\mathrm{CH}_{2} \mathrm{NCSe}\right]$ ) (3b). Compound $\mathbf{3 b}$ was prepared by the above method and purified by column chromatography using 9:1 hexanes/EtOAc to afford $\mathbf{3 b}(95 \%)$ as a white solid: $\mathrm{mp}$ 89-91 ${ }^{\circ} \mathrm{C} ; R_{f}$ value 0.51 ( $n$-hexane/EtOAc 4:1); $[\alpha]_{\mathrm{D}}^{25}-122.4$ (c 1.0, $\left.\mathrm{CHCl}_{3}\right)$; IR (KBr) $\nu 1697,2148 ;{ }^{1} \mathrm{H} \mathrm{NMR}\left(300 \mathrm{MHz}, \mathrm{CDCl}_{3}\right) \delta 0.95(6 \mathrm{H}$, d, $\left.J=5.2 \mathrm{~Hz},-\mathrm{CH}\left(\mathrm{CH}_{3}\right)_{2}\right), 1.45\left(9 \mathrm{H}, \mathrm{s},-\mathrm{C}\left(\mathrm{CH}_{3}\right)_{3}\right), 1.47-1.70(3 \mathrm{H}, \mathrm{m}$, $\left.-\mathrm{CH}_{2}-\mathrm{CH}\left(\mathrm{CH}_{3}\right)_{2}\right), 3.55-3.77\left(2 \mathrm{H}, \mathrm{m},-\mathrm{CH}_{2}-\mathrm{NCSe}\right), 4.61(1 \mathrm{H}, \mathrm{m}$, $\left.-\mathrm{CH}-\mathrm{CH}_{2}-\mathrm{NCSe}\right), 5.48(1 \mathrm{H}, \mathrm{br}, \mathrm{NH}) ;{ }^{13} \mathrm{C} \mathrm{NMR}\left(100 \mathrm{MHz}, \mathrm{CDCl}_{3}\right)$ $\delta$ 22.1, 24.8, 28.4, 40.8, 48.3, 49.8, 58.9, 80.2, 124.5, 155.1; ${ }^{77}$ Se NMR $\left(\mathrm{CDCl}_{3}\right) \delta-357.6$; MS (ESI-HR) $m / z$ calcd for $\mathrm{C}_{12} \mathrm{H}_{23} \mathrm{~N}_{2} \mathrm{NaO}_{2} \mathrm{Se}$ 329.0744 $\left(\mathrm{M}+\mathrm{Na}^{+}\right)$, found $329.0739\left(\mathrm{M}+\mathrm{Na}^{+}\right)$.

4.5.2. (S)-Benzyl 1-isoselenocyanatopropan-2-ylcarbamate (Z-Ala- $\Psi$ $\left.\left[\mathrm{CH}_{2} \mathrm{NCSe}\right]\right)(\mathbf{4 a})$. Compound $4 \mathbf{a}$ was prepared by the above method and purified by column chromatography using $5: 1$ hexanes/EtOAc to afford $4 \mathbf{a}(91 \%)$ as gum. $R_{f}$ value 0.49 (n-hexane/EtOAc $\left.4: 1\right)$; $[\alpha]_{D}^{25}$ -11.6 (c 1.0, $\mathrm{CHCl}_{3}$ ); IR (neat) $\nu 1714,2148 ;{ }^{1} \mathrm{HNMR}\left(300 \mathrm{MHz}, \mathrm{CDCl}_{3}\right.$ ) $\delta 1.25\left(3 \mathrm{H}, \mathrm{d}, \mathrm{J}=4.9 \mathrm{~Hz},-\mathrm{CH}-\mathrm{CH}_{3}\right), 3.35-3.55\left(2 \mathrm{H}, \mathrm{m}, \mathrm{CH}_{2}-\mathrm{NCSe}\right)$, $4.20\left(1 \mathrm{H}, \mathrm{m},-\mathrm{CH}-\mathrm{CH}_{2}-\mathrm{NCSe}\right), 5.10\left(2 \mathrm{H}, \mathrm{s}, \mathrm{Ar}-\mathrm{CH}_{2}-\right), 7.23-7.48(5 \mathrm{H}$, $\mathrm{m}, \mathrm{ArH}) ;{ }^{13} \mathrm{C}$ NMR $\left(100 \mathrm{MHz}, \mathrm{CDCl}_{3}\right) \delta 20.6,53.4,62.2,69.0,128.1$, $128.5,128.7,128.9,134.6,155.1 ;{ }^{77} \mathrm{Se} \mathrm{NMR}\left(\mathrm{CDCl}_{3}\right) \delta-356.6$; MS (ESI) $m / z$ calcd for $\mathrm{C}_{12} \mathrm{H}_{14} \mathrm{~N}_{2} \mathrm{O}_{2} \mathrm{Se} 321.0\left(\mathrm{M}+\mathrm{Na}^{+}\right)$, found $321.0\left(\mathrm{M}+\mathrm{Na}^{+}\right)$.

\subsection{General procedure for the synthesis of $N^{\beta}-B o c / Z-$ protected unsymmetrical selenoureas 12 and selenoureidopeptides 13}

To a solution of $N^{\beta}$-Boc/Z-amino alkyl isoselenocyanate 3 or $\mathbf{4}$ $(1 \mathrm{mmol})$ in $\mathrm{CH}_{2} \mathrm{Cl}_{2}(15 \mathrm{~mL})$, a solution of amino acid ester (1.3 mmol, obtained by neutralizing the corresponding salt with equimolar quantity of NMM in $\mathrm{CH}_{2} \mathrm{Cl}_{2}$ ) or an organic amine was added and the reaction mixture was stirred at room temperature for about $30 \mathrm{~min}$. After the completion of reaction as monitored by TLC, it was diluted with $\mathrm{CH}_{2} \mathrm{Cl}_{2}(10 \mathrm{~mL}), 10 \%$ citric acid solution $(10 \mathrm{~mL})$ was added and the layers were separated. The organic layer was subsequently washed with water, brine and finally dried over anhydrous sodium sulfate. It was concentrated in vacuo to afford the title compounds as pure solids.

4.6.1. (S)-tert-Butyl 1-(3-(3-chlorophenyl)selenoureido)-3-methylbutan2-ylcarbamate (Boc-Val- $\Psi\left[\mathrm{CH}_{2} \mathrm{NHCSeNH}\right]-m-\mathrm{Cl}_{-} \mathrm{C}_{6} \mathrm{H}_{4}$ ) (12a). Compound 12a was prepared by the above method and purified by column chromatography using 7:3 hexanes/EtOAc to afford 12a (88\%) as a white solid: $\mathrm{mp} 139-141{ }^{\circ} \mathrm{C} ; R_{f}$ value 0.40 ( $n$-hexane/ EtOAc 1:1); IR (neat) $\nu 1546,1693 ;{ }^{1} \mathrm{H} \mathrm{NMR}\left(300 \mathrm{MHz}, \mathrm{CDCl}_{3}\right) \delta 0.95$ $\left(6 \mathrm{H}, \mathrm{d}, \mathrm{J}=5.6 \mathrm{~Hz},-\mathrm{CH}\left(\mathrm{CH}_{3}\right)_{2}\right), 1.32\left(9 \mathrm{H}, \mathrm{s},-\mathrm{C}\left(\mathrm{CH}_{3}\right)_{3}\right), 1.82(1 \mathrm{H}, \mathrm{m}$, $\left.-\mathrm{CH}\left(\mathrm{CH}_{3}\right)_{2}\right), 3.59\left(1 \mathrm{H}, \mathrm{m},-\mathrm{CH}-\mathrm{CH}_{2}-\mathrm{NH}-\right), 3.65-3.80(2 \mathrm{H}, \mathrm{m}$, $\left.-\mathrm{CH}-\mathrm{CH}_{2}-\mathrm{NH}-\right), 4.72(1 \mathrm{H}, \mathrm{br}, \mathrm{NH}), 7.19-7.55(4 \mathrm{H}, \mathrm{m}, \mathrm{ArH}), 8.67$ $(1 \mathrm{H}, \mathrm{br}, \mathrm{NH}) ;{ }^{13} \mathrm{C}$ NMR $\left(100 \mathrm{MHz}, \mathrm{CDCl}_{3}\right) \delta 18.1,28.1,30.7,52.7,55.4$, 79.9, 123.2, 125.2, 127.2, 130.8, 135.4, 137.2, 157.0, 179.1; ${ }^{77}$ Se NMR $\left(\mathrm{CDCl}_{3}\right) \delta$ 261.1; MS (ESI) $\mathrm{m} / z$ calcd for $\mathrm{C}_{17} \mathrm{H}_{26} \mathrm{ClN}_{3} \mathrm{O}_{2} \mathrm{Se} 442.1$ $\left(\mathrm{M}+\mathrm{Na}^{+}\right)$, found $442.2\left(\mathrm{M}+\mathrm{Na}^{+}\right)$. Anal. Calcd for $\mathrm{C}_{17} \mathrm{H}_{26} \mathrm{ClN}_{3} \mathrm{O}_{2} \mathrm{Se}: \mathrm{C}$, 48.75; H, 6.26; N, 10.03. Found: C, 48.77; H, 6.29; N, 10.04 .

4.6.2. (S)-Methyl 2-(3-((S)-2-(benzyloxycarbonyl)-4-(methylthio)butyl)selenoureido) propanoate (Z-Met- $\Psi\left[\mathrm{CH}_{2} \mathrm{NHCSeNH}\right]-$ Ala-OMe) (13d). Compound 13b was prepared by the above method and purified by column chromatography using 5:1 hexanes/EtOAc to afford 13b (95\%) as gum; $R_{f}$ value 0.35 ( $n$-hexane/EtOAc 1:1); IR (neat) $\nu 1512,1693,1740 ;{ }^{1} \mathrm{H}$ NMR $\left(300 \mathrm{MHz}, \mathrm{CDCl}_{3}\right) \delta 1.10-1.45$ $\left(3 \mathrm{H}, \mathrm{d}, J=5.7 \mathrm{~Hz},-\mathrm{CH}-\mathrm{CH}_{3}\right), 1.81-2.00\left(2 \mathrm{H}, \mathrm{m},-\mathrm{CH}_{2}-\mathrm{CH}_{2}-\mathrm{S}-\right)$, $2.05\left(3 \mathrm{H}, \mathrm{s},-\mathrm{S}-\mathrm{CH}_{3}\right), 2.55\left(2 \mathrm{H}, \mathrm{m},-\mathrm{CH}_{2}-\mathrm{CH}_{2}-\mathrm{S}-\right), 3.48-3.56(2 \mathrm{H}$, $\left.\mathrm{m},-\mathrm{CH}-\mathrm{CH}_{2}-\mathrm{NH}-\right), 3.68\left(3 \mathrm{H}, \mathrm{s},-\mathrm{COOCH}_{3}\right), 3.82(1 \mathrm{H}, \mathrm{m}$, $\left.-\mathrm{CH}-\mathrm{CH}_{2}-\mathrm{N}-\right), 3.89(1 \mathrm{H}, \mathrm{m},-\mathrm{NH}-\mathrm{CH}-), 5.31\left(2 \mathrm{H}, \mathrm{s}, \mathrm{Ar}-\mathrm{CH}_{2}-\right)$, $7.14-7.48(5 \mathrm{H}, \mathrm{m}, \mathrm{ArH}) ;{ }^{13} \mathrm{C} \mathrm{NMR}\left(100 \mathrm{MHz}, \mathrm{CDCl}_{3},\right) \delta$ 17.5, 17.9, 29.9, 31.9, 48.2, 49.5, 53.4, 56.2, 67.2, 127.1, 127.3, 127.6, 128.3, 128.6, 137.2, 155.4, 172.6, 183.2; ${ }^{77} \mathrm{Se} \mathrm{NMR}\left(\mathrm{CDCl}_{3}\right) \delta 262.2$; MS (ESI-HR) $\mathrm{m} / z$ calcd for $\mathrm{C}_{18} \mathrm{H}_{27} \mathrm{~N}_{3} \mathrm{O}_{4} \mathrm{SSe} 484.0785\left(\mathrm{M}+\mathrm{Na}^{+}\right)$, found $484.0781\left(\mathrm{M}+\mathrm{Na}^{+}\right)$.

\section{Acknowledgements}

Financial supports from the Department of Science and Technology (grant no. SR/S1/OC-26/2008) and Council of Scientific and Industrial Research (grant no. 01(2323)/09/EMR-II), Govt. of India are gratefully acknowledged. We thank Bangalore University, Bangalore for partial financial support. C.K. thanks CSIR, Govt. of India for Senior Research Fellowship. We also acknowledge the Departments of Organic Chemistry, Inorganic \& Physical Chemistry and Sophisticated Instrument Facility, Indian Institute of Science, Bangalore for recording NMR and mass spectra. We thank Prof. K.M. Sivanandaiah for his support and useful discussions and Dr. H.N. Gopi, IISER, Pune, India for the needful assistance.

\section{Supplementary data}

General remarks and product characterization data for all the new compounds along with selected copies of IR, ${ }^{1} \mathrm{H}$ NMR, ${ }^{13} \mathrm{C}$ NMR, ${ }^{77}$ Se NMR, and HRMS spectra and crystal structure details and CIFs of the compounds $\mathbf{7 d}, \mathbf{3 a}, \mathbf{3 d}$, and $\mathbf{4 c}$ are provided. Supplementary data associated with this article can be found in the online version, at doi:10.1016/j.tet.2010.06.082.

\section{References and notes}

1. Albada, H. B.; Soulimani, F.; Weckhuysen, B. M.; Liskamp, R. M. J. Chem. Commun. 2007, 4895-4897. 
2. Peptide-Based Drug Design: Controlling Transport and Metabolism; Taylor, M. D., Amidon, G. L., Eds.; American Chemical Society: Washington, DC, 1995 and references cited therein.

3. Pseudo-Peptides in Drug discovery; Nielsen, P. E., Ed.; Wiley-VCH GmbH KGaA: Weinheim, Germany, 2004 and references cited therein.

4. Nowick, J. S. Acc. Chem. Res. 2008, 41, 1319-1330.

5. Sureshbabu, V. V.; Naik, S. A.; Hemantha, H. P.; Narendra, N.; Das, U.; Row, T. N. G. J. Org. Chem. 2009, 74, 5260-5266.

6. (a) For biological role of OrgSeCs including nutritional significance of Se see: Selenium in Trace Elements in Human and Animal Nutrition; Levander, O. A., Mertz, W., Eds.; Academic: Orlando, FL, 1986; Vol. 2, p 209; (b) For the chemistry of biologically important synthetic OrgSeCs see: Mugesh, G.; du Mont, W.W.; Sies, H. Chem. Rev. 2001, 101, 2125-2180; (c) Mugesh, G.; Singh, H. B. Chem. Soc. Rev. 2000, 29, 347-357.

7. For pharmacological effects of OrgSeCs see: Nogueira, C. W.; Zeni, G.; Rocha, J. B. T. Chem. Rev. 2004, 104, 6255-6286.

8. (a) Fitzmaurice, J. C.; Williams, D. J.; Wood, P. T.; Woollins, J. D. J. Chem. Soc. Chem. Commun. 1988, 741-743; (b) Hua, G.; Li, Y.; Slawin, A. M. Z.; Woollins, J. D. Org. Lett. 2006, 8, 5251-5254.

9. (a) Ishihara, H.; Koketsu; Fukuta, Y.; Nada, F. J. Am. Chem. Soc. 2001, 123 , 8408-8409; (b) Koketsu, M.; Fukuta, Y.; Ishihara, H. J. Org. Chem. 2002, 67, 1008-1011.

10. Knapp, S.; Darout, E. Org. Lett. 2005, 7, 203-206.

11. Clive, D. L. J.; Yang, W. Chem. Commun. 1996, 1605-1606.

12. Geisler, K.; Jacobs, A.; Kunzler, A.; Mathes, M.; Girrleit, I.; Zimmermann, B.; Bulka, E.; Pfeiffer, W.-D.; Langer, P. Synlett 2002, 1983-1986.

13. Saravanan, V.; Mukherjee, C.; Das, S.; Chandrasekaran, S. Tetrahedron Lett. 2004, 45, 681-683.

14. Plutin, A. M.; Suarez, M.; Ochoa, E.; Machado, T.; Mocelo, R.; Concellon, J. M.; Rodriguez-Solla, H. Tetrahedron 2005, 61, 5812-5817.

15. Koketsu, M.; Ishida, M.; Takakura, N.; Ishihara, H. J. Org. Chem. 2002, 67, 486-490.

16. (a) Garud, D. R.; Tanahashi, N.; Ninomiya, M.; Koketsu, M. Tetrahedron 2009, 65, 4775-4780; (b) Nazari, M.; Movassagh, B. Tetrahedron Lett. 2009, 50, 1453-1455.

17. For other selected examples see: Asanuma, Y.; Fujiwara, S.-i.; Shin-ike, T.; Kambe, N. J. Org. Chem. 2004, 69, 4845-4848.

18. (a) Fujiwara, S.-i.; Asanuma, Y.; Shin-ike, T.; Kambe, N. J. Org. Chem. 2007, 72 , 8087-8090; (b) Koketsu, M.; Kogami, M.; Ando, H.; Ishihara, H. Synthesis 2006, 31-36; (c) Geisler, K.; Pfeiffer, W.-D.; Muller, C.; Nobst, E.; Bulka, E.; Langer, P. Synthesis 2003, 1215-1220.

19. Koketsu, M.; Takahashi, A.; Ishihara, H. J. Heterocycl. Chem. 2007, 44, 79-81.

20. (i) For $(1 \rightarrow n)$ linked selenodisaccharides synthesis see: (a) Kawai, Y.; Ando, $\mathrm{H}_{\text {. }}$ Ozeki, H.; Koketsu, M.; Ishihara, H. Org. Lett. 2005, 7, 4653-4656; (b) Czernecki, S.; Randriamandimby, D. J. Carbohydr. Chem. 1996, 15, 183-190; (c) For C-glycosides: Johnston, B. D.; Pinto, B. M. Carbohydr. Res. 1998, 305, 289-292; For Oglycosides preparation and applications see: (d) Yamago, S.; Kokubo, K.; Hara, O.; Masuda, S.; Yoshida, J.-i. J. Org. Chem. 2002, 67, 8584-8592; (e) Yamago, S.; Yamada, T.; Hara, O.; Ito, H.; Mino, Y.; Yoshida, J.-i. Org. Lett. 2001, 3 3867-3870; (f) For selenoglycoconjugates: Jiaang, W.-T.; Chang, M.-Y.; Tseng, P.-H.; Chen, S.-T. Tetrahedron Lett. 2000, 41, 3127-3130; (g) For other selected reports see: Mukherjee, C.; Tiwari, P.; Misra, A. K. Tetrahedron Lett. 2006, 47, 441-445.

21. (a) Stadtman, T. C. Annu. Rev. Biochem. 1996, 65, 83-100; (b) Allmang, C.; Krol, A. Biochimie 2006, 88, 1561-1571.

22. Flohe, L.; Andreesen, J. R.; Brigelius-Flohe, R.; Maiorino, M.; Ursini, F. IUBMB Life 2000, 49, 411-420.

23. For a recent review on selenopeptide chemistry including a summary of peptides and proteins synthesized such as selenoglutathione, selenooxytocin, somatostatin, selenosubtilisin, metalloselenoein, selenoglutathione, glutaredoxin, endothelin-1, apamin, interleukin, [C754U]-RNA (745-761), [C110U]RNase A, [C38U]-BPTI, conotoxin ImI, glutaredoxin 3, see: Muttenthaler, M.; Alewood, P. F. J. Pept. Sci. 2008, 14, 1223-1239 and references cited therein.

24. Bock, A.; Forchhammer, K.; Heider, J.; Leinfelder, W.; Sawers, G.; Veprek, B.; Zinoni, F. Mol. Microbiol. 1991, 5, 515-520.

25. For selected reports on synthesis of selenocysteine see: (a) Stocking, E. M.; Schwarz, J. N.; Senn, H.; Salzmann, M.; Silks, L. A. J. Chem. Soc., Perkin Trans. 1 1997, 25, 2443-2448; (b) Siebum, A. H. G.; Woo, W. S.; Rapp, J.; Lugtenburg. J. Eur. J. Org. Chem. 2004, 2905-2913; For Z-Sec(Bzl)-OH see: (c) Walter, R.; Chan, W. Y. J. Am. Chem. Soc. 1967, 89, 3892-3898; (d) For Fmoc-Sec(Mob)-OH see Theodoropoulos, D.; Schwartz, I. L.; Walter, R. Biochemistry 1967, 6 3927-3932; (e) Koide, T.; Itoh, H.; Otaka, A.; Yasui, H.; Kuroda, M.; Esaki, N.; Soda, K.; Fujii, N. Chem. Pharm. Bull. 1993, 41, 502-506; (f) Gieselman, M. D. Xie, L.; van der Donk, W. A. Org. Lett. 2001, 3, 1331-1334; For Boc-Sec(MeBzl)OH see: (g) Oikawa, T.; Esaki, N.; Tanaka, H.; Soda, K. Proc. Natl. Acad. Sci. U.S.A 1991, 88, 3057-3059; (h) Armishaw, C. J.; Daly, N. L.; Nevin, S. T.; Adams, D. J. Craik, D. J.; Alewood, P. F. J. Biol. Chem. 2006, 281, 14136-14143.

26. For reviews on incorporation of Sec through the biosynthetic routes including expressed protein ligation, transfection of eukaryotic cells, recombinant seleproduction techniques see: (a) Stadtman, T. C. Science 1974, 183, 915-922; (b) Caban, K.; Copeland, P. R. Cell. Mol. Life Sci. 2006, 63, 73-81.

27. For a review on selenium containing enzymes in mammals and their biological role see: Roy, G.; Sarma, B. K.; Phadnis, P. P.; Mugesh, G. J. Chem. Sci. 2005, 117, 287-303.

28. Sies, H. Angew. Chem., Int. Ed. Engl. 1986, 25, 1058-1071.

29. (a) Metanis, N.; Keinan, E.; Dawson, P. E. J. Am. Chem. Soc. 2006, 128 16684-16691; (b) Quaderer, R.; Hilvert, D. Chem. Commun. 2002, 2620-2621.

30. Braga, A. L.; Ludtke, D. S.; Paixao, M. W.; Alberto, E. E.; Stefani, H. A.; Juliano, L. Eur. J. Org. Chem. 2005, 4260-4264.

31. (i) For the synthesis of aliphatic isoselenocyanates see: (a) Sonoda, N.: Yamamoto, G.; Tsutsumi, S. Bull. Chem. Soc. Jpn. 1972, 45, 2937-2938; (ii) For viny isoselenocyanates see: (b) Banert, K.; Toth, C. Angew. Chem., Int. Ed. Engl. 1995 34, 1627-1629; (iii)For substituted benzyl selenocyanates see: (c) Jacob, L. A. Matos, B.; Mostafa, C.; Rodriguez, J.; Tillotson, J. K. Molecules 2004, 9, 622-626.

32. For reviews see: (a) Garud, D. R.; Koketsu, M.; Ishihara, H. Molecules 2007, 12 , 504-535; (b) Koketsu, M.; Ishihara, H. Curr. Org. Synth. 2007, 4, 15-29.

33. Barton, D. H. R.; Parekh, S. I.; Tajbakhsh, M.; Theodorakis, E. A.; Tse, C.-L. Tetrahedron 1994, 50, 639-654

34. (a) Suzuki, H.; Usuki, M.; Hanafusa, T. A. Synthesis 1979, 705-707; (b) Koketsu, M.; Suziki, N.; Ishihara, H. J. Org. Chem. 1999, 64, 6473-6475; For other reports see: (c) Zhou, Y: Heimgartner, H. Helv. Chim. Acta 2000, 83, 539-553.

35. For reports on $\mathrm{CSe}_{2}$ see: (a) Werner, J. S. J. Org. Chem. 1963, 28, 1642-1644; (b) Werner, J. S.; Page, T. F., Jr. J. Org. Chem. 1966, 31, 606-607; (c) Henriksen, L. Ehrbar, U. Synthesis 1976, 519-521.

36. For a protocol to isoselenocyanates preparation via cycloaddition by the reaction of nitrile oxides with selenoamides see: Ref. 34b.

37. Nowick, J. S.; Powell, N. A.; Nguyen, T. M.; Noronha, G. J. Org. Chem. 1992, 57, 7364-7366.

38. Nowick, J. S.; Holmes, D. L.; Noronha, G.; Smith, E. M.; Nguyen, T. M.; Huang, S. L. J. Org. Chem. 1996, 61, 3929-3934.

39. Sureshbabu, V. V.; Patil, B. S.; Venkataramanarao, R. J. Org. Chem. 2006, 71, 7697-7705.

40. (a) For the preparation and isolation of isocyanates derived from Fmoc- $\alpha$ amino acids see: Patil, B. S.; Vasanthakumar, G.-R.; Sureshbabu, V. V. J. Org Chem. 2003, 68, 7274-7280; (b) For the generation of isocyanates starting from Boc-amino acids and their conversion to $O$-succinimidyl carbamates: Sureshbabu, V. V.; Sudarshan, N. S.; Kantharaju. Synth. Commun. 2008, 38 2168-2184; (c) For reports on the generation of Z-Tyr-NCO, Z-Gly-NCO and Z-Phe-NCO from corresponding azides see: Kawasaki, K.; Maeda, M.; Watanabe, J.; Kaneto, H. Chem. Pharm. Bull. 1988, 36, 1766-1771.

41. For the generation of isocyanates derived from $\beta$-amino acids and their conversion to active carbamates using Boc-chemistry see: (a) Guichard, G. Semetey, V.; Didierjean, C.; Aubry, A.; Briand, J.-P.; Rodriguez, M. J. Org. Chem. 1999, 64, 8702-8705; (b) Fmoc-chemistry see: Guichard, G.; Semetey, V.; Rodriguez, M.; Briand, J.-P. Tetrahedron Lett. 2000, 41, 1553-1557; (c) Fischer, L; Semetey, V.; Lozano, J.-M.; Schaffner, A. P.; Briand, J.-P.; Didierjean, C.; Guichard, G. Eur. J. Org. Chem. 2007, 2511-2525.

42. For a patent on Z-NH-CH$-\mathrm{CH}_{2}-\mathrm{NCO}$, see: Chen, M. H.; Nargund, R.; Patchett, A A.; Yang, L. U.S. Patent 5,721,251, 1998.

43. For useful discussion of formamide and isonitrile derivatives of $N$-protected amino acids, literature protocols for their preparation and their applications, see Supplementary data.

44. Sureshbabu, V. V.; Narendra, N.; Nagendra, G. J. Org. Chem. 2009, 74, 153-157.

45. Tantry, S. J.; Kantharaju; Suresh Babu, V. V. Tetrahedron Lett. 2002, 43, 9461-9462.

46. For selected reports on selenoureas from 2001 onwards, see: (a) Koketsu, M Ishihara, H. Curr. Org. Synth. 2006, 3, 439-455; (b) Garud, D. R.; Koketsu, M. Org. Lett. 2008, 10, 3319-3322. 